\title{
Components of job satisfaction among offshore catering crew: a preliminary investigation
}

\begin{abstract}
This paper attempts to investigate the components of job satisfaction among offshore catering crews in which could be in similar or different context with those working onshore. The study found that pay is the most significant factor of job satisfaction, since the work is paying more in comparison with similar work onshore. Other factors identified are the nature of work, workplace facilities and co-worker need further investigation and elaboration. However, one thing could be certain in this study, the acknowledgment of offshore catering industry and its uniqueness could be really helpful in disseminating information and investigating crucial issues which helps in refining the industry and placing it as one of the main components and future career paths in hospitality industry in Malaysia.
\end{abstract}

Keyword: Job satisfaction; Isolated environment; Offshore catering crew 